\title{
FORMULATION AND EVALUATION OF NAPROXEN PRONIOSOMAL GEL FOR THE TREATMENT OF INFLAMMATORY AND DEGENERATIVE DISORDERS OF THE MUSCULOSKELETAL SYSTEM
}

\author{
Varsha Gadekar *, Mithun Bhowmick, Girijesh Kumar Pandey, Amit Joshi, Balkrishna Dubey \\ TIT College of Pharmacy, Bhopal, India \\ *Corresponding Author's E-mail: varshugadekar4@gmail.com
}

\begin{abstract}
Non-ionic surfactant based Proniosome Gels of naproxen sodium, an cox II inhibitor, were prepared by coacervation phase separation method. The prepared systems were characterised for encapsulation efficiency, shape, size and in vitro drug release. Stability study was carried out to investigate the leaching of drug from the proniosomal system during storage. The results showed that naproxen in all the formulations was successfully entrapped and a substantial change in release rate and an alteration in the encapsulation efficiency of naproxen from proniosomes were observed upon varying the type of surfactant and cholesterol content. The encapsulation efficiency of proniosomes prepared with Span 40:60 was superior to that prepared with all Span prepration. A preparation with Span 40: 60, cholesterol and lecithin gave maximum encapsulation efficiency $(84.61 \%)$ and release results $(\mathrm{Q} 24 \mathrm{~h}=81 \%)$ as compared to other compositions. Proniosomal formulations showed fairly high retention of naproxen inside the vesicles at refrigerated temperature $\left(4-8^{\circ} \mathrm{C}\right)$ up to 1 month.
\end{abstract}

Keywords: Naproxen, proniosomes, Niosomes, encapsulation efficiency, drug delivery.

\section{INTRODUCTION:}

Non-steroidal anti-inflammatory drugs (NSAIDs) are among the drugs most commonly used to reduce inflammation and pain. NSAIDs inhibit cyclooxygenase2 enzyme system results in anti-inflammatory action, while inhibition of the Cox-1 enzyme system results in anti-inflammatory action as well as gastric irritation. The main factor limiting the oral use of NSAIDs is the development of gastrointestinal (GI) adverse events, ranging from dyspepsia to serious life-threatening events. Several studies have shown the effectiveness of topical NSAIDs in treating acute and chronic soft tissue conditions. Naproxen sodium [(S)-6-methoxy-alphamethyl-2naphthaleneacetic acid sodium salt] is an NSAID with analgesic and antipyretic properties used for the treatment of musculoskeletal disorders with non-optimal characteristics to be delivered through the skin. The advantage of a NSAID gel over its oral equivalent is that therapeutic benefit can be achieved, while significantly reducing any potential systemic side effects. The plasma concentration achieved via topical delivery is $1-10 \%$ of that attained by oral medication and therefore has a significantly reduced risk of potentially serious side effects. Proniosomal Gels can resist the physiological stress caused by skin flexion, mucociliary movement, adopting to the shape of the applied area and for controlling drug release. Proniosome, a dry product in gel form may avoid many of the problems associated with aqueous noisome dispersions and minimize problems of physical stability (aggregation, fusion or leaking).

\section{MATERIALS AND METHODS:}

\section{Materials}

Drug: Naproxen Sodium

Excipients: Non-ionic surfactants such as span 20, span 40 \& span 60, Lecithin, Cholesterol

\section{Methods}

Method of Preparation of $\begin{aligned} & \text { Naproxen Loaded } \\ & \text { Coacervation-Phase }\end{aligned}$
Proniosomal Gel Using
Separation Technique ${ }^{17,18,50,51}$

Proniosomal gel was prepared by a coacervation-phase separation technique. Precisely weighed amounts of surfactant, lecithin, cholesterol and drug were taken in a clean and dry wide mouthed glass vial of $5.0 \mathrm{ml}$ capacity and alcohol $(1.0 \mathrm{ml})$ was added to it. After warming, all the ingredients were mixed well with a glass rod; the open end of the glass bottle was covered with a lid to prevent the loss of solvent from it and warmed over water bath at $60-70^{\circ} \mathrm{C}$ for about 5 min until the surfactant mixture was dissolved completely. Then the aqueous phase (phosphate buffer saline $\mathrm{pH}$ 7.4) was added and warmed on a water bath till a clear solution was formed which was converted into Proniosomal gel on cooling. The gel so obtained was preserved in the same glass bottle in dark conditions for characterization. Compositions of proniosomal gel formulations are given in Table 1. 


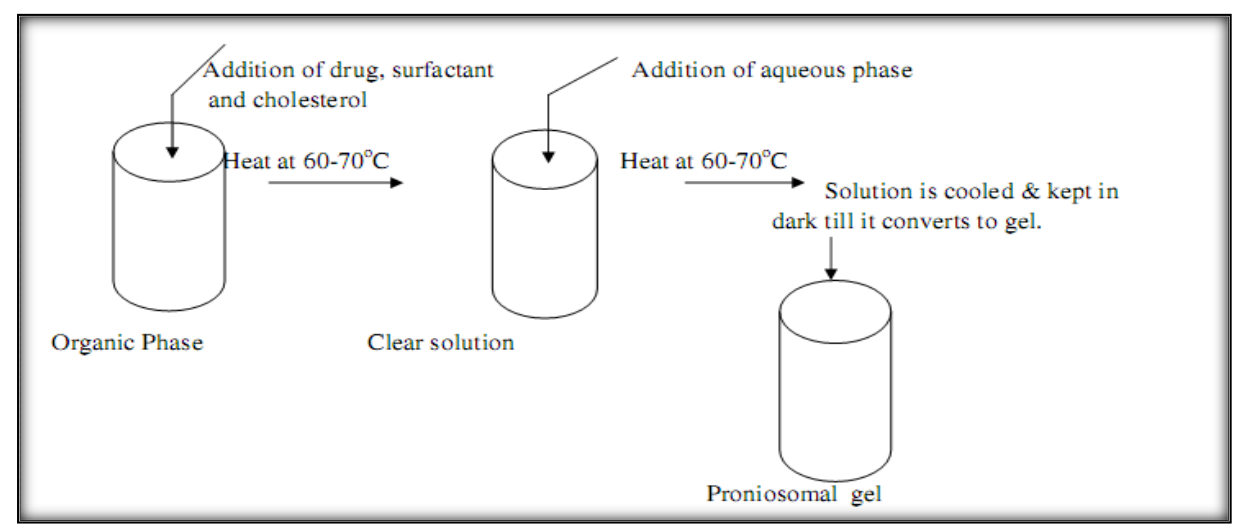

Figure 1: Method of Preparation of Proniosomal Gel

Table 1: Formulation Design

\begin{tabular}{|c|c|c|c|c|c|c|c|}
\hline $\begin{array}{c}\text { Formulation } \\
\text { code }\end{array}$ & $\begin{array}{c}\text { Drug } \\
(\mathbf{m g})\end{array}$ & $\begin{array}{c}\text { Non-ionic } \\
\text { surfactants }\end{array}$ & $\begin{array}{c}\text { Ratio } \\
(\mathbf{m g})\end{array}$ & $\begin{array}{c}\text { Lecithin } \\
(\mathbf{m g})\end{array}$ & $\begin{array}{c}\text { Cholestrol } \\
(\mathbf{m g})\end{array}$ & $\begin{array}{c}\text { Ethanol } \\
(\mathbf{m l})\end{array}$ & $\begin{array}{c}\text { PBS } \\
\mathbf{p H ~ 7 . 4}(\mathbf{m l})\end{array}$ \\
\hline PN1 & 10 & Span 20 & 1000 & 100 & 100 & 1.0 & 0.5 \\
\hline PN2 & 10 & Span 40 & 1000 & 100 & 100 & 1.0 & 0.5 \\
\hline PN3 & 10 & Span 60 & 1000 & 100 & 100 & 1.0 & 0.5 \\
\hline PN4 & 10 & Span 20:Span 40 & $500: 500$ & 100 & 100 & 1.0 & 0.5 \\
\hline PN5 & 10 & Span 40: Span 60 & $500: 500$ & 100 & 100 & 1.0 & 0.5 \\
\hline PN6 & 10 & Span 20: Span 60 & $500: 500$ & 100 & 100 & 1.0 & 0.5 \\
\hline
\end{tabular}

\section{Characterization of Proniosomal Gel}

\section{Morphological Evaluation}

A. Physical Appearance ${ }^{50}$ : The prepared gel was viewed by naked eye to characterize color and physical state of gel. The appearance for each formula was checked such as color, consistency and fluidity and comparison of each one with the other.

B. Optical Microscopic Examination: Hydration of proniosomal gel (100mg) was done by adding PBS 7.4 $(5 \mathrm{ml})$ in a small glass vial with occasional shaking for $10 \mathrm{~min}$. An optical microscope with a camera attachment was used to observe the shape of the prepared niosomal vesicles.

C. Vesicle Size Analysis ${ }^{51}$ :Size and size distribution studies were done for niosomes prepared from proniosomes hydration with agitation (shaking) and without agitation size Analysis was done by adding saline solution $(0.9 \%$ solution $)$ to the proniosomal gel (100mg) in a small glass vial with occasional shaking for $10 \mathrm{~min}$. After hydration, the dispersion of niosomes was observed under optical microscope (Olympus) at 100, 40 and 10x magnification. The sizes of 150-200 vesicles were measured using a calibrated ocular and stage micrometer fitted in the optical microscope

D. Surface Morphology ${ }^{17,60}$ : Electron micrographs were obtained using scanning electron microscope. The surface morphology (roundness, smoothness and formation of aggregates) of proniosomal gel was studied by Scanning Electron Microscopy .Hydration of proniosomal gel was done similarly as optical microscopy. One drop of niosomal suspension was mounted on clear glass slab, air dried and sputtercoated with gold palladium $(\mathrm{Au} / \mathrm{Pd})$ using a vacuum evaporator (Edwards) and examined using a scanning electron microscope equipped with a digital camera, at 15 or $20 \mathrm{kV}$ accelerating voltage.

Determination of $\mathbf{p H}^{\mathbf{1 4 , 5 0 , 8 0}}$ : The $\mathrm{Ph}$ of the Proniosomal gels were determined by digital $\mathrm{pH}$ meter. One gram of gel was dissolved in $25 \mathrm{ml}$ of distilled water and the electrode was then dipped in to gel formulation for $30 \mathrm{~min}$ until constant reading obtained. And constant reading was noted. The measurements of $\mathrm{pH}$ of each formulation were replicated two times.

\% Encapsulation Efficiency ${ }^{\mathbf{5 0}}$ : The concentration of drug entrapped was determined by taking $0.2 \mathrm{~g}$ of proniosomal gel, weighed in a glass tube and added to 10 $\mathrm{ml}$ of $\mathrm{pH} 7.4$ phosphate buffer. The aqueous suspension was sonicated in a sonicator bath. The drug-containing Niosomes were separated from untrapped drug by centrifugation at $18000 \mathrm{rpm}$ at $5^{\circ} \mathrm{C}$ for $40 \mathrm{~min}$. The supernatant clear fraction was used for the determination of free drug and assayed for drug content. The percentage of drug encapsulation (\% EE) was calculated by the following equation:

$$
\% E E=\frac{C_{t}-C_{f}}{C_{t}} \times 100
$$

Where, $\mathrm{Ct}=$ total concentration of drug, $\mathrm{Cf}=$ concentration of free drug.

\section{In Vitro Skin Permeation Studies ${ }^{50,51}$}

Preparation of Human cadaver skin: The skin was stored at $0-4^{\circ} \mathrm{C}$ after collection. The excised human abdomen skin was treated to remove hair and subdermal tissue. The subdermal fat was removed with help of scalpel and swapped with isopropyl alcohol. The treated skin was stored at $0^{\circ} \mathrm{C}$ in deep freezer for not more than 2 days. To actually mimic the in vitro permeation study, the permeation studies were performed using excised cadaver skin mounted on Franz cell. The capacity of 
receptor compartment was $20 \mathrm{ml}$. The area of donor compartment exposed to receptor compartment was 2.0 $\mathrm{cm}^{2}$. The cadaver skin was mounted between the donor and receptor compartment. A weighed amount of proniosomal gel equivalent to $10 \mathrm{mg}$ of naproxen was placed on one side of the membrane. The receptor medium was saline phosphate buffer $\mathrm{pH}$ 7.4. The receptor compartment was surrounded by a water jacket to maintain the temperature at $37 \pm 1^{\circ} \mathrm{C}$. Heat was provided using a thermostatic hot plate with a magnetic stirrer. The receptor fluid was stirred by a Teflon-coated magnetic bead fitted to a magnetic stirrer. At each sampling interval, (1 ml) were withdrawn and were replaced by equal volumes of fresh receptor fluid on each occasion. Samples withdrawn were analyzed spectrophotometrically at 230 $\mathrm{nm}$.

Data Analysis via Drug Release Kinetics study ${ }^{17}$ :The results of in-vitro release profile obtained for all the formulations were plotted in kinetic models as follows, 1.Cumulative of drug released versus time (zero order kinetic model). 2. Log cumulative percent drug remaining to be absorbed versus time (First order model) 3 . Cumulative amount of drug release versus square root of time (Higuchi model) 4. Log cumulative drug released versus log time ( Korsmeyer-Peppas model)

Skin Irritation Test ${ }^{18}$ :Skin irritation study was performed by using control, standard skin irritant, placebo and test placebo niosomal gel. Primary skin irritation test was performed since skin is a vital organ through which drug is transported. Skin irritation studies were performed on healthy rabbits (average weight: 1.5 to $2.25 \mathrm{~kg}$ ). The dorsal surface $\left(50 \mathrm{~cm}^{2}\right)$ of the rabbits was cleaned, and the hair was removed by shaving. The skin was cleansed with rectified spirit. The best formulation was placed over the skin and was removed after $24 \mathrm{hrs}$. The resulting skin reaction was evaluated according to score as per Table.

\section{RESULTS AND DISCUSSION: \\ CHARACTERIZATION OF PRONIOSOMAL GEL}

\section{Morphological Evaluation}

A. Physical Appearance: Table shows the color and physical state for each formula, these properties are differ from each other since they depend on the composition. For example, formula PN2 \& PN3 gave a white semisolid appearance whereas PN1 showed a brown liquid, this is due to the property of span 40, span 60 and span 20 for each formula respectively. The inspection of formula PN4, PN5 and PN6 offered the light brownish color with gel state at $37^{\circ} \mathrm{C}$ which represents the combination of the surfactants cause a change in the physical properties of surfactant after mixing and addition of alcohol with a few drops of water.

Table 2: Physical Appearance of Proniosomal formulation

\begin{tabular}{|c|c|c|}
\hline $\begin{array}{c}\text { Formulation } \\
\text { Code }\end{array}$ & Colour & Physical State \\
\hline PN1 & Brown & Liquid \\
\hline PN2 & White & Semi-solid \\
\hline PN3 & White & Semi-solid \\
\hline PN4 & Light-brown & Gel \\
\hline PN5 & Light brown & Gel \\
\hline PN6 & Light-brown & Gel \\
\hline
\end{tabular}

B. Optical Microscopic Examination: Hydration of proniosomal gel $(100 \mathrm{mg}$ ) was done by adding PBS 7.4 $(5 \mathrm{ml})$ in a small glass vial with occasional shaking for 10 min. An optical microscope with a camera attachment was used to observe the shape of the prepared niosomal vesicles.

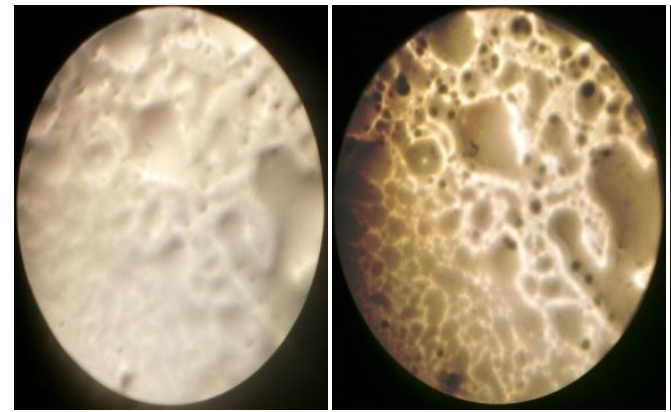

Formulation - 1

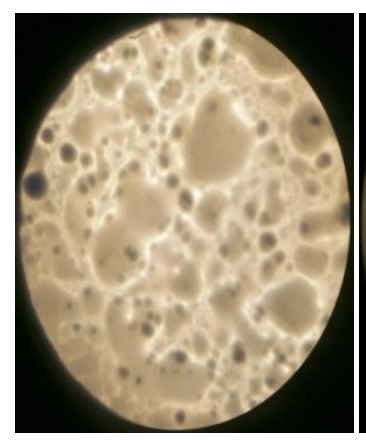

Formulation -4
Formulation - 2

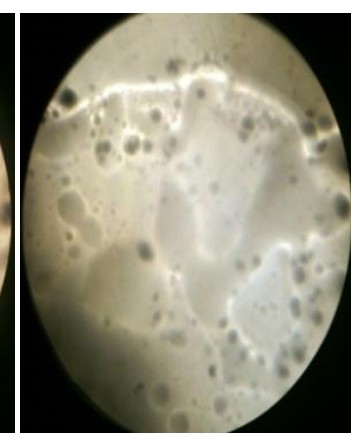

Formulation $-\mathbf{5}$

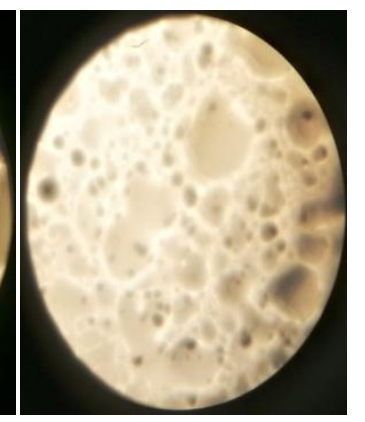

Formulation - 3

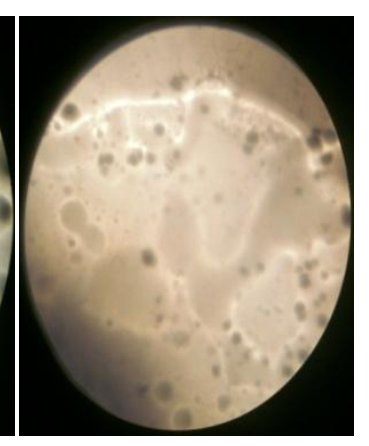

Formulation -6

Figure 2: Optical Microscopic Examination of different Proniosomal formulation 
Vesicle Size Analysis: Determination of vesicle size is important for the topical application of vesicles. Size was reduced when the dispersion was agitated. The reason for this is the energy applied in the agitation which results in the breakage of the larger vesicles to smaller vesicles.

Table 3: Vesicle Size Analysis

\begin{tabular}{|c|c|c|}
\hline $\begin{array}{c}\text { Formulation } \\
\text { code }\end{array}$ & $\begin{array}{c}\text { Mean vesicles size } \\
\text { before shaking } \\
(\boldsymbol{\mu m})\end{array}$ & $\begin{array}{c}\text { Mean vesicles } \\
\text { size after } \\
\text { shaking }(\boldsymbol{\mu m})\end{array}$ \\
\hline PN1 & 4.23 & 1.91 \\
\hline PN2 & 3.87 & 1.75 \\
\hline PN3 & 3.05 & 1.43 \\
\hline PN4 & 4.09 & 1.97 \\
\hline PN5 & 3.20 & 1.66 \\
\hline PN6 & 4.15 & 2.12 \\
\hline
\end{tabular}

Surface Morphology: The morphology of niosomes derived from proniosomal gel was studied using Scanning Electron Microcopy. SEM revealed that the niosomes formed were nearly spherical and homogenous.

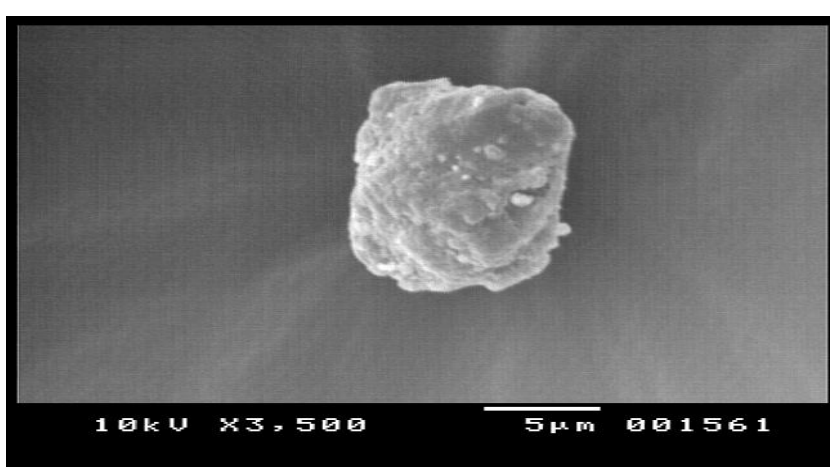

Figure 3: Scanning electron image of hydrated proniosomal formulation PN5 (magnification 1,000 X)

Determination of $\mathbf{p H}$ : The $\mathrm{pH}$ of each formula was determined in order to investigate the possibility of any side effects in vivo. Due to acidic or alkaline $\mathrm{pH}$ which may irritate skin. The $\mathrm{pH}$ was found between 6.4 and 7.5, this range is within the physiologically skin surface $\mathrm{pH}$. Changes in the $\mathrm{pH}$ are reported to play a role in the pathogenesis of skin diseases like irritant contact dermatitis and atopic dermatitis. Maintaining the skin's $\mathrm{pH}$ factor helps maintain a proper balance of the "acid mantle" which aids in protecting the body from bacteria and helps prevent moisture loss.

Table 4: pH Determination

\begin{tabular}{|c|c|}
\hline FORMULATION & $\mathbf{p H}$ \\
\hline PN1 & 6.4 \\
\hline PN2 & 6.9 \\
\hline PN3 & 7.3 \\
\hline PN4 & 6.8 \\
\hline PN5 & 7.5 \\
\hline PN6 & 6.7 \\
\hline
\end{tabular}

\% Encapsulation Efficiency: Table. 4 shows the effect of various sorbitan fatty acid esters and their ratio on the encapsulation of Naproxen in proniosomal gel. Naproxen was best encapsulated by proniosomal prepared using Spans 40 and 60 . This might be attributed to fact that
Spans 40 and 60 are solid at room temperature and showed a higher phase transition temperatures [Tc]

Table 5: \% Encapsulation Efficiency

\begin{tabular}{|c|c|}
\hline Formulation & \% Encapsulation Efficiency \\
\hline PN1 & 65.22 \\
\hline PN2 & 77.56 \\
\hline PN3 & 78.81 \\
\hline PN4 & 71.16 \\
\hline PN5 & 84.61 \\
\hline PN6 & 74.11 \\
\hline
\end{tabular}

(F) In-Vitro Release Study

Graph 1: Zero order release kinetics Data

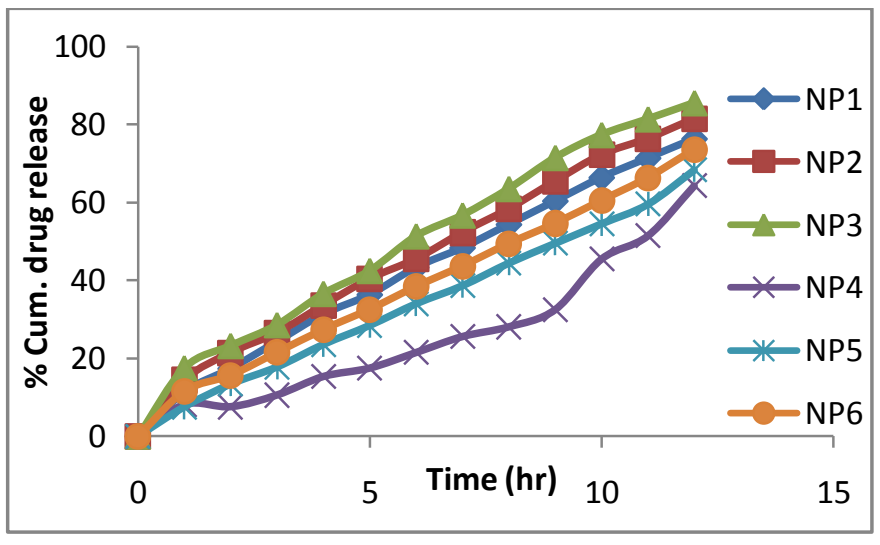

Graph 2: First Order Release Kinetics Data

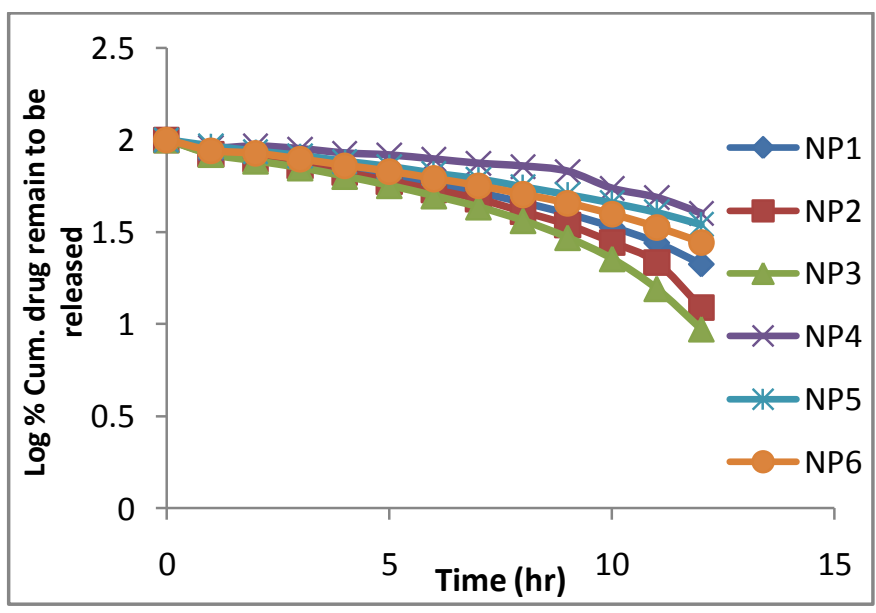

Graph 3: Higuchi matrix release kinetics data

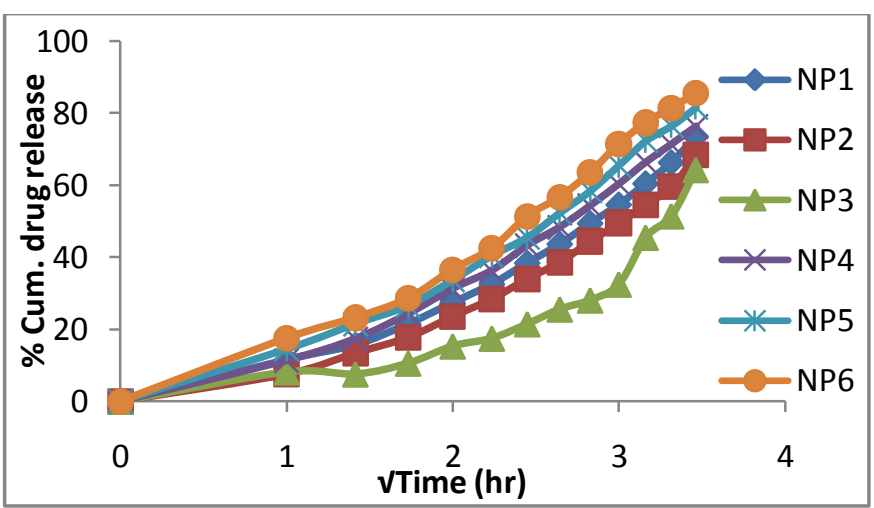

ISSN: 2250-1177

CODEN (USA): JDDTAO 
Graph 4: Peppas release kinetics data

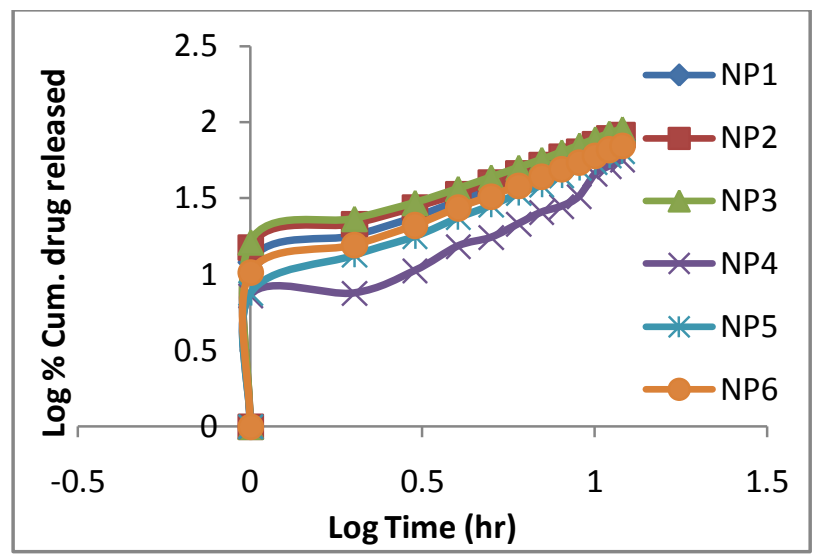

Drug Release Kinetics with Model Fitting: Calculated regression co-efficient for different formulations are shown in Table. These values of in-vitro release were attempted to fit into various mathematical models, plot of zero order, first order, higuchi matrix and peppas. These values were compared with each other for model fitting equation. Based on the highest regression values (r), the bestfit model for PN1, PN2, and PN3 was Zero order and for PN4, PN5, and PN6 was Peppas. Further Korsmeyer and Peppas equation resulted into the values of $n>1$, which appears to indicate that the release from the prepared microspheres was by Super Case II transport.

Table 6: Drug Release Kinetics with Model Fitting

\begin{tabular}{|c|c|c|c|c|c|c|}
\hline \multirow{2}{*}{$\begin{array}{c}\text { Formulation } \\
\text { code }\end{array}$} & \multicolumn{3}{|c|}{ Correlation coefficient of Model fitting $\left(\mathbf{R}^{\mathbf{2}}\right)$} & \multirow{2}{*}{$\begin{array}{c}\text { ' values } \\
\text { for Peppas }\end{array}$} & \multirow{2}{*}{ Best fit model } \\
\cline { 2 - 6 } & Zero order & First order & Higuchi matrix & Peppas kinetics & \\
\hline NP1 & 0.9903 & 0.9627 & 0.9508 & 0.9759 & 2.2538 & Zero Order \\
\hline NP2 & 0.9814 & 0.8855 & 0.9298 & 0.9797 & 2.2386 & Zero Order \\
\hline NP3 & 0.9676 & 0.8844 & 0.9044 & 0.9673 & 2.2864 & Zero Order \\
\hline NP4 & 0.9544 & 0.8968 & 0.8822 & 0.9701 & 2.2167 & Peppas Model \\
\hline NP5 & 0.9497 & 0.8921 & 0.8754 & 0.9668 & 2.2109 & Peppas Model \\
\hline NP6 & 0.9186 & 0.8467 & 0.8317 & 0.9666 & 2.1168 & Peppas Model \\
\hline
\end{tabular}

Skin irritation studies: The optimized formulation PN5 showed irritation potential of ' 0 ', thus proving to be non irritant. The ' 0 ' value in an irritancy test indicates that the applied formulations are generally non irritant to human skin. No obvious erythema and edema were observed on rabbit skin after $24 \mathrm{hr}$ of application of the optimized formulation. Moreover, the optimized formulation is composed of phospholipids, a natural component of the cell membranes in skin; they act as nonirritating moisturizing agents.

Table 7: Possible score for skin irritation

\begin{tabular}{|c|c|c|}
\hline TEST & SKIN REACTION & SCORE \\
\hline \multirow{3}{*}{ Erythema } & Very slight erythema & 0 \\
\cline { 2 - 3 } & Well defined erythema & 0 \\
\cline { 2 - 3 } & Moderate to severe erythema & 0 \\
\cline { 2 - 3 } Edema & Severe edema & 0 \\
\hline & Very slight erythema & 0 \\
\cline { 2 - 3 } & Well defined erythema & 0 \\
\cline { 2 - 3 } & Moderate to severe erythema & 0 \\
\cline { 2 - 3 } & Severe edema & 0 \\
\hline
\end{tabular}

\section{REFERENCES}

1. Touitou E, Dayan N, Bergelson L, Godin B Eliaz M.Ethosomesnovel vesicular carriers for enhanced delivery: characterization and skin penetration properties. J Control Release 2000; 65: 403-418.

2. Jain S, Jain P, Umamaheshwari RB, Jain NK. Transfersomes - a novel vesicular carrier for enhanced transdermal delivery: Development, characterization, and performance evaluation. Drug Dev Ind Pharm 2003; 29(9): 1013-1026.

3. Schreier H, Bouwstra J. Liposomes and niosomes as topical drug carriers for dermal and transdermal drug delivery. J Control Rel 1994; 30: 1-15.

4. Verma DD, Verma S, Blume G, Fahr A. Liposomes increase skin Penetration of entrapped and non-entrapped hydrophilic

\section{CONCLUSION:}

In the present study, an attempt will be made to prepare and evaluate Naproxen sodium proniosomal gels by coacervation-phase separation method for the treatment of inflammatory and degenerative disorders of the musculoskeletal system. The exhaustive literature survey has been done on Vesicle system, Pro-vesicle system, their method of preparations, various excipients so that a stable Proniosomal formulation of Naproxen sodium can be formulated which can release drug for number of hours and exhibit good anti- inflammatory activity.The Transdermal Proniosomal Gels showed controlled drug release properties. The results of the present study indicated that Naproxen proniosomal gel containing lecithin, cholesterol and in combination of surfactants like span 20, 40 and 60 produce sustained release of drug over a period of $12 \mathrm{hrs}$ for the treatment of inflammatory and degenerative disorders of the musculoskeletal system. The proniosomal gel could be an effective alternative vehicle for delivering the drug through transdermal route to avoid side effects associate with oral route. substances into human skin:a skin penetration and confocal laser scanning microscopy study. Eur J Biopharm 2003; 55: 271-277.

5. Kaur IP, Garg A, Singla AK, Aggarwal D. Vesicular systems in ocular drug delivery: An overview. Int J Pharm 2004; 269: 1-14.

6. Biju SS. Vesicular Systems: An Overview. Ind Jour Pharm Sci 2006; 68(2): 141-153.

7. Fahima H, Mohamed EIR, Mohamed N, Yasmin A.Preparation and characterization of niosomes containing ribavirin for liver targeting. Drug Deliv 2010; 17(5): 282-287.

8. Singh SK, Rajera R, Nagpal K, Mishra DN. Niosomes: A controlled and novel drug delivery system. Biol Pharm Bull 2011; 34(7): 945-953. 
9. Aungst BJ. Novel formulation strategies for improving and bioavailability with poor membrane permeation. J Pharm Sci 1993; 82: 871-879.

10. Balakrishnan P, Shanmugam S, Lee WS, Lee WM, Kim JO, Oh DH, Kim DD, Kim JS, Yoo BK, Choi HG, Woo JS, Yong CS, et al. Formulation and in vitro assessment of minoxidil niosomes for enhanced skin delivery. Int J Pharm 2009; 377: 1-8.

11. Uchegbu IF, Vyas SP. Non-ionic surfactant based vesicles (niosomes) in drug delivery. Int J Pharm 1998; 172: 33-70.

12. Varshosaz J, Pardakhty A, Hajhashemi V, Najafabadi AR. Development and physical characterization of sorbitan monoester niosomes for insulin oral delivery. Drug Deliv 2003; 10: 251-262.

13. Junyaprasert VB, Teeranachaideekul V, Supaperm T. Effect of charged and non-ionic membrane additives on physicochemical properties and stability of niosomes. AAPS PharmSciTech 2008; 9(3): 851-859.

14. Attia IA, El-Gizawy SA, Fouda MA, Donia AM. Influence of a niosomal formulation on the oral bioavailability of acyclovir in rabbits. AAPS Pharm Sci Tech 2007; 8(4): 106.

15. Vyas SP, Khar RK. Niosomes, Targeted and Controlled Drug delivery, 1st edition 2002; 249-279.

16. Satturwar PM, Fulzele SV, Nande VS, Khandare JN. Formulation and evaluation of ketoconazole Niosomes. Indian J Pharm 2002; 64(2): 155-158.

17. Vora B, Khopade AJ, Jain NK. Proniosome based transdermal delivery of levonorgestrel for effective contraception. J Control Release 1998; 54: 149-165.

18. Laithy HM, Shoukry O, Mahran LG. Novel sugar esters proniosomes for transdermal delivery of vinpocetine: Preclinical and clinical studies. Eur J Pharm Biopharm 2011; 77(1): 43-51.

19. Biju SS, Talegaonkar S, Misra PR, Khar RK. Vesicular systems: An overview. Indian J Pharm Sci 2006; 68: 141-153.

20. Shukla ND, Tiwari M. Proniosomal drug delivery system: clinical applications. International Journal of Research in Pharmaceutical and Biomedical Sciences 2011; 2(3): 880-887.

21. Elbary AA, El-laithy HM, Tadros MI. Sucrose aterate based proniosomes derived niosomes for the nebulisable delivery of cromolyn sodium. Int J Pharm 2008; 357(1-2): 189-198.

22. Menon GK: New insights into skin structure: scratching the surface. Adv Drug Del Rev 2002; 54: S3-S17.

23. Bouwsta JA, Honeywell-Nguye PL. Skin structure and mode of action on vesicles. Adv Drug Del 2002; 54: S41-S55.

24. Vanhal D, Vanrensen A, Devringer T, Junginger H, Boustra J. Diffusion of estradiol from nonionic surfactant vesicles through human stratum-corneum in vitro. STP Pharma Sci 1996; 6: 72-78.

25. Cevc G. Lipid vesicles and other colloids as drug carriers on the skin. Int J pharm 2004; 56: 675-711.

26. Prausnitz MR, Mitragotri S, Langer R. Current status and future potential of transdermal drug delivery. Nat Rev Drug Discov 2004; 3: 115-124.

27. Elsayed MA, Abdallah OY, Naggar VF, Khalafallah NM. Deformable liposomes and ethosomes: Mechanism of enhanced skin delivery. International Journal of Pharmaceutics 2006; 322: 60-66.

28. Yadav K, Yadav D, Saroha K, Nanda S, Mathur P, Syan N, et al. Proniosomal Gel: A provesicular approach for transdermal drug delivery. Der Pharmacia Lettre 2010; 2(4): 189-198.

29. Kakar R, Rao R, Goswami A, Nanda S, Saroha K. Proniosomes: An Emerging Vesicular System in Drug Delivery and Cosmetics. Der Pharmacia Lettre 2010; 2(4): 227 239.

30. Hofland $\mathrm{H}$, Geest RV, Bodde $\mathrm{H}$, Junginger $\mathrm{H}$, Boustra J. Estradiol permeation from non ionic surfactant vesicles through human stratum corneum in vitro. Pharmaceut Res 1994; 11: 659-664.
31. Runothayanun P, Sooksawate T, Florence AT. Extrusion of niosomes from capillaries: approaches to pulsed delivery device. J Control Release, 1999; 60(2): 391-397.

32. Arunothayanun P, Bernard MS, craig DQM, Uchegbu IF, Florence AT. The effect of processing variables on the physical characterstics of non ionic surfactant vesicles (niosomes) formed from a hexadecyl diglycerol ether. Int $\mathbf{J}$ Pharm 2000; 201:7-14.

33. Kibbe AH. Handbook of Pharmaceutical Excipients, 3rd edn. American Pharmaceutical Association, Washington D.C 2000: 511-514.

34. Hao Y, Zhao F, Li N, Yang Y, Li K. Studies on a high encapsulation of colchicine by a noisome system. Int J Pharm 2002; 244: 73-80.

35. Reddy DN, Udupa N. Formulation and evaluation of oral and transdermal preparations of flurbiprofen and piroxicam incorporated with different carriers.Drug Dev Ind Pharm 1993; 19: 843-852.

36. Valenta C, Wanka M, Heidlas J. Evaluation of novel soyalecithin formulations for dermal use containing ketoprofen as a model drug. J Control. Rel 2000; 63: 165-173.

37. Nasseri B. Effect of cholesterol and temperature on the elastic properties of niosomal membranes. Int J Pharm 2005; 300: 95101.

38. Fang JY, Hong CT, Chiu WT, Wang YY. Effect of liposomes and niosomes on skin permeation of Enoxacin. Int J Pharm 2001; 21: 61-72.

39. Finean JB. Interaction between cholesterol and phospholipid in hydrated bilayers. Chem Phy Lipids 1990; 54: 147-156.

40. Lopez JM, Gonzalez ML, Rabasco AM. Effect of cholesterol and ethanol on dermal delivery from DPPC liposomes. Int J Pharm 2005; 298: 1-12.

41. Ishii F, Takemura A, Ishigami Y. Procedure for preparation of lipid vesicles (Liposomes) using coacervation (phase separation) technique. Langmuir 1995; 11: 483-486.

42. Parikh DK, Ghosh TK. Feasibility of transdermal delivery of fluoxetine. AAPS PharmSciTec 2005; 6(2): 144-149.

43. Annakula D, Errabelli MR, Jukanti R, Bandari S, Veerareddy PR. Provesicular drug delivery systems: An overview and appraisal. Arch Appl Sci Res 2010; 2(4): 135-146.

44. Megrab NA, Williams AC, Barry BW. Oestradiol permeation across human skin, silastic and snake skin membranes: The effects of ethanol/water co-solvent systems. Int J Pharm 1995; 116: $101-112$.

45. Sudaxshiina M, Benedicte VD, Gregory G, Alexander TF. Water in sorbitan monostearate organogels (water in oil gels). J Pharm Sci 1999; 88(6): 615-619.

46. Almira I, Blazek-Welsh, Rhodes DG. SEM Imaging Predicts Quality of Niosomes from Maltodextrin-Based Proniosomes. Pharmaceutical Research 2001; 18(5): 656-661.

47. Aggarwal D, Garg A, Kaur IP. Development of a topical niosomal preparation of acetazolamide: preparation and evaluation. J Pharm Pharmacol 2004; 56(12): 1509-1517.

48. Shahiwala A, Misra A. Studies in topical application of niosomally entrapped nimesulide. J Pharm Pharm Sci 2002; 5 : 220-225.

49. Youan, BC, Hussain A, Nguyen NT. Evaluation of sucrose estersas alternative surfactants in micro-encapsulation of proteins by the solvent evaporation method. AAPS PharmSciTech 2003; 5(22).

50. Gupta KS, Nappinnai M, Gupta VRM. Formulation and evaluation of topical meloxicam niosomal gel. Int J Biopharm 2010; 1: 7-13.

51. Kakkar R, Rao R, Dahiya NK, Nanda S. Formulation and characterization of valsartan proniosomes. Maejo Int $\mathrm{J}$ Sci Technol 2011; 5(01): 146-158.

Huang JY, Jung BH, Chung SJ, Lee MH, Shim CK. In vitro skin permeation of nicotine from proliposomes. J Contr Release 1997; 49: 177-184. 